\section{Uunnværlig håndbok for helsestasjoner}

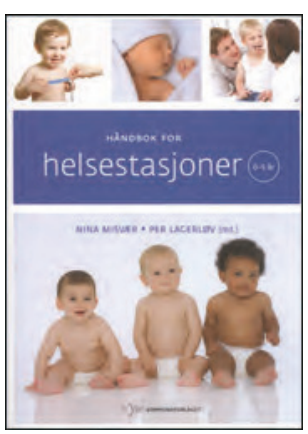

Nina Misvær, Per Lagerløv, red.

Håndbok for helsestasjoner 0-5 år

5. utg. 422 s, tab, ill. Oslo: Kommuneforlaget, 2013. Pris NOK 578

ISBN 978-82-446-2038-3

Dette er femte revisjon av Håndbok for helsestasjoner. Redaktørene, som er henholdsvis helsesøster og barnelege, har med seg et solid team av medforfattere med bakgrunn fra bl.a. medisin, fysioterapi, psykologi og odontologi. Målgruppen er helsesøstre og helsestasjonsleger og andre fagfolk som jobber med barn.

De 19 kapitlene spenner fra rutineundersøkelser, kommunikasjon og fysioterapi til barneulykker og evidensbasert medisin. Det er gode tabeller og oversikter, noen tegninger og et lite utvalg bilder bakerst. Viktige budskap er plassert i uthevede tekstbokser. Kapitteloversikten er fyldig og god, men indeksen er temmelig mager. Språket er godt, layouten pen og ryddig, og redaktørene har sydd sammen bidragene fra de mange forfatterne til en god og helhetlig tekst.

Jeg hadde gleden av å anmelde den forrige utgaven, i 2006, og hadde lite å klage på den gang. Alle de gode elementene fra tidligere utgaver er med. I tillegg er flere temaer utvidet og forbedret, bl.a. kommunikasjon, kunnskapsbasert praksis og søvn og ernæring. Det er ett nytt kapittel om fysioterapi og ett om familien. Kapitlet om kommunikasjon er enda bedre enn sist, med bred dekning av ulike metoder, tilnærming til spesielle grupper og problemstillinger og gode refleksjoner om fagfolkenes rolle. Stikkord er ekspertrollen versus konsulentrollen, styrking (empowerment) og mestringsmodeller.

Ett av ankepunktene mine ved forrige utgave var at temaet innvandrerfamilier var svakt dekket. I den nye utgaven er dette atskillig forbedret, og temaet er inkorporert i mange kapitler på en utmerket måte. Det samme gjelder psykisk sykdom hos foreldre og parkommunikasjon og konflikter.

Jeg savner et par temaer. Det ene er alvorlige problemer i familien, som rus, overgrep og mishandling. Det andre er juridiske forhold, f.eks. når man har meldeplikt til barnevernet. Jeg savner også noen ord om kjønnslemlestelse og omskjæring. Endelig stusser jeg over at cøliaki ikke er nevnt, verken under matintoleranse eller barnesykdommer.

Men disse ankepunktene må ses på som forbedringsforslag, ikke kritikk. Hovedinntrykket er at dette er en meget solid og grundig bok som jeg varmt kan anbefale til alle som arbeider med barn, enten de er leger, helsesøstre, fysioterapeuter eller studenter. Jeg vil gå så langt som å si at den er uunnværlig.

Pernille Nylehn

Spesialist i allmennmedisin, Kvinneklinikken

Haugesund sjukehus

\section{Pediatrisk ekkokardiografi på norsk}

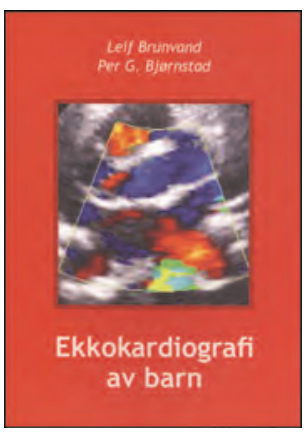

Leif Brunvand, Per G. Bjørnstad Ekkokardiografi av barn

147 s., ill. Oslo: Kolofon forlag, 2013.

Pris NOK 300

ISBN 978-82-300-1064-8

Ekkokardiografi er et uvurderlig hjelpemiddel hos pasienter med medfødt hjertefeil. Metoden forutsetter imidlertid både praktisk trening og detaljert fagkunnskap om de ulike hjertefeilenes anatomi og patofysiologi. En nybegynner kan lett bli overveldet, spesielt når lærebøker i faget gjerne består av flere tusen sider med engelsk fagsjargong.

Denne norskspråklige innføringsboken, skrevet av to nestorer i faget, er derfor svært velkommen. Boken retter seg mot barneleger med spesiell interesse for barnekardiologi, voksenkardiologer som arbeider med medfødte hjertefeil, og ekkoteknikere.

Innledningsvis omtales kort praktiske og tekniske forhold, deretter basale målinger (avstander, blodstrømshastigheter osv.). Hoveddelen er viet en systematisk gjennomgang av alle hjertets deler med beskrivelse av både normalitet og patologi, inkludert hvilke ekkokardiografiske mål som er særlig informative ved hver enkelt hjertefeil. Avslutningsvis er det korte kapitler om ekkokardiografi i nyfødtperioden, om undersøkelser etter intervensjonell/kirurgisk behandling og om andre barnekardiologiske problemstillinger.

Den største utfordringen med lærebøker i ekkokardiografi er å «oversette» undersøkelsens dynamiske karakter - der man ved hjelp av levende bilder kan lete målrettet etter bestemte strukturer til tekst og figurer. Det blir som å skrive en lærebok i sykling det kan aldri bli en fullgod erstatning for å trene med sykkelen! Desto viktigere er det med en pedagogisk disposisjon, presist språk og gode illustrasjoner. Her lykkes forfatterne stort sett utmerket. Den systematiske gjennomgangen av hjertets ulike deler er logisk bygd opp og analog til hvordan undersøkelsen gjennomføres i praksis. Språket beskriver entydig den ofte komplekse anatomien ved medfødte hjertefeil - men enkelte ganger blir setningene kanskje unødig tunge. De ekkokardiografiske stillbildene er gjennomgående av høy kvalitet og valgt ut med omhu. Forlaget kunne gjerne spandert mer plass på dem, for enkelte er gjengitt i så forminsket utgave at det kan være vanskelig å se detaljer.

Fremstillingen har et visst universitetssykehus-perspektiv «hverdagskardiologien» har fått forholdsvis liten plass. Boken vil derfor være av størst utbytte for kolleger som allerede har noe praktisk erfaring. Den anbefales likevel varmt til alle med barnekardiologiske interesser.

\section{Vegard Bruun Wyller}

Tidsskriftet 